\title{
Distribusi Spasial dan Faktor Kontaminasi Logam Berat di Pesisir Kota Makassar
}

\author{
Rahmat Januar Noor ${ }^{1 *}$, Arnold Kabangnga'2, Fathuddin 1 \\ IProgram Studi llmu Kelautan, Sekolah Tinggi Teknologi Kelautan Balik Diwa Makassar \\ 2Program Studi Pemanfaatan Sumberdaya Perairan, STITEK Balik Diwa Makassar \\ Jl. Perintis Kemerdekaan VIII no. 8, Makassar, 90245 Indonesia \\ Email: rahmat_jn@stitek-balikdiwa.ac.id
}

\begin{abstract}
Spatial Distribution and Contamination Factor of Heavy Metal in Makassar Coastal Area

The presence of heavy metals in coastal waters is a threat to the wealth of coastal ecosystems because they are toxic. The people activities of Makassar City are centered in the coastal area so that they have the potential to produce heavy metal pollutants that can escape into coastal waters. This study aimed to determine the distribution of heavy metal concentrations in the sediment and water column and to determine the contamination factor. The research location is along the coast of Makassar City by determining the location of the observation based on potential sources of input, namely ports, river estuaries, and tourism activities. The research method used survey methods with in-situ measurements (oceanographic parameters) and ex-situ (heavy metal concentrations) and data presentation using tables, graphs, and analysis of variance test results. The concentration of heavy metals $\mathrm{Pb}, \mathrm{Cd}$, and $\mathrm{Zn}$ in the sediment were higher and significantly different $(\mathrm{p}<0.05)$ compared to the water column, while Cu not different. There was no significant difference in the concentration of heavy metals ( $p>0.05$ ) spatially (ports, river estuaries, tourist sites). Heavy metals in the sediments did not exceed the quality standard, while several heavy metals in the water column exceeded the quality standards, namely $\mathrm{Pb}$ and $\mathrm{Cd}$. The contamination level of heavy metal pollutants studied in the coastal waters of Makassar City was low (CF <1), and if sorted, a pattern of heavy metal was $\mathrm{Cd}>\mathrm{Zn}>\mathrm{Pb}>\mathrm{Cu}$.
\end{abstract}

Keywords : heavy metal, sediment, water body, contamination factor

\begin{abstract}
Abstrak
Keberadaan logam berat di perairan pesisir merupakan ancaman bagi kekayaan ekosistem pesisir sebab bersifat toksik. Aktivitas masyarakat Kota Makassar berpusat di daerah pesisir sehingga berpotensi menghasilkan bahan pencemar logam berat yang dapat lepas ke perairan pesisir. Penelitian ini bertujuan untuk mengetahui distribusi konsentrasi logam berat di sedimen dan kolom air serta menentukan faktor kontaminasi. Lokasi penelitian di sepanjang pesisir Kota Makassar dengan penentuan lokasi pengamatan berdasarkan potensi sumber masukan yaitu pelabuhan, muara sungai, dan aktivitas wisata. Metode penelitian menggunakan metode survey dengan pengukuran secara insitu (parameter oseanografi) dan exsitu (konsentrasi logam berat) serta penyajian data menggunakan tabel, grafik, dan hasil pengujian analisis varians. Konsentrasi logam berat $\mathrm{Pb}, \mathrm{Cd}$, dan $\mathrm{Zn}$ pada sedimen lebih tinggi serta berbeda secara signifikan $(p<0,05)$ dibandingkan dengan kolom air sedangkan Cu tidak berbeda. Tidak terdapat perbedaan konsentrasi logam berat yang nyata $(p>0,05)$ secara spasial (pelabuhan, muara sungai, lokasi wisata) Logam berat pada sedimen tidak melampaui baku mutu sedangkan pada kolom air terdapat beberapa logam berat yang melampaui baku mutu yaitu $\mathrm{Pb}$ dan $\mathrm{Cd}$. Tingkat kontaminasi bahan pencemar logam berat yang diteliti di perairan pesisir Kota Makassar termasuk rendah (CF $<1)$ dan bila diurutkan maka ditemui pola $\mathrm{Cd}>\mathrm{Zn}>\mathrm{Pb}>\mathrm{Cu}$.
\end{abstract}

Kata kunci : logam berat, sedimen, kolom air, faktor kontaminasi 


\section{PENDAHULUAN}

Pesisir merupakan wilayah yang rentan terhadap perubahan lingkungan karena mempertemukan dua entitas sehingga perubahan di darat ataupun laut akan memengaruhi kondisi pesisir (Dahuri et al., 2013). Pembangunan yang massif di wilayah pesisir semakin mengeskalasi tekanan lingkungan yang berasal jauh dari pesisir (Yan et al., 2018). Pesisir merupakan daerah dengan topografi landai sehingga menjadi muara dari berbagai material yang berpotensi menjadi bahan pencemar(Hettige et al., 2014; Noor, 2019).

Material yang masuk ke perairan pesisir mengalami transport oleh arus pasang surut, pengenceran, koagulasi dan sedimentasi, asosiasi dengan bahan organik sedimen, dan diserap oleh plankton (Rangkuti et al., 2017) sehingga dapat berdampak pada ekosistem pesisir. Material antropogenik yang patut diwaspadai ialah logam berat karena dapat tersebar secara temporal dan spasial (Budiyanto \& Lestari, 2017; Drira et al., 2017) sehingga berbahaya bagi biota dan manusia (Werorilangi et al., 2016). Selain dari faktor antropogenik, sumber alami logam berat yaitu dari pengikisan batuan mineral dan partikel logam di atmosfer yang turun melalui hujan. (Najamuddin et al., 2016) mengemukakan bahwa masukan logam berat pada badan air didominasi oleh aktivitas di pesisir.

Salah satu kota di pesisir dengan pembangunan intensif ialah Kota Makassar yang ditunjukkan dengan angka pertumbuhan ekonomi mencapai $7,07 \%$, di atas pertumbuhan ekonomi nasional $(5,17 \%)$ (BPS, 2019). Pesisir Kota Makassar terbentang sepanjang $32 \mathrm{~km}$, terdiri atas satu daratan utama dan 11 pulau kecil. Masukan bahan pencemar di kawasan pesisir Makassar dapat berasal dari sungai ( $S$. Tallo dan $S$. Jeneberang), kanal, dan aktivitas masyarakat di daerah pesisir (Wanna et al., 2018). Potensi bahan pencemar masuk ke perairan pesisir semakin besar mengingat adanya pemusatan kegiatan manusia di pesisir yang ditunjukkan oleh makin luasnya jumlah lahan yang tertutup bangunan dari $6.478 \mathrm{Ha}$ (2001) menjadi 9.839 Ha (2015) (Amri et al., 2018).
Data konsentrasi logam berat di pesisir Kota Makassar terpantau pada beberapa hasil penelitian yang menguji konsentrasi logam berat di kolom air dan sedimen. Pada tahun 2013-2014 menunjukkan konsentrasi logam Pb sekitar 0,097-0,110 ppm, Cd sekitar 0,030-0,729 ppm, dan Cu sekitar 0,020-0,165 ppm dan tahun 2015-2016 konsentrasi $\mathrm{Pb}$ sekitar 2,372-5,694 ppm, Cd sekitar 0,351-0,695 ppm, dan $\mathrm{Hg}$ sekitar 0,569-1,382 ppm (Setiawan, 2015; Supriadi, 2016). Konsentrasi logam berat $\mathrm{Pb}$ dan $\mathrm{Cd}$ di sedimen pada perairan pesisir Kota Makassar sekitar 0,38-2,58 ppm dan 0,05-0,25 ppm (Werorilangi et al., 2016). Distribusi logam $\mathrm{Pb}$ dan $\mathrm{Zn}$ secara terlarut berurutan sekitar 0,016-0,198 ppm dan $<0,002-0,083$ ppm sedangkan pada kondisi partikulat berturut-turut berkisar 0,465-2,182 ppm dan 19,329-80,283 ppm (Najamuddin et al., 2016).

Pada uraian di atas dapat diketahui bahwa konsentrasi logam di perairan pesisir Kota Makassar sangat dinamis dan terdapat parameter yang telah melebihi baku mutu. Penelitian ini bertujuan untuk mengetahui distribusi konsentrasi logam berat yang terdapat di perairan pesisir Kota Makassar baik pada badan air maupun sedimen dasar dengan meninjau konsentrasi logam $\mathrm{Pb}, \mathrm{Cd}$, $\mathrm{Cu}, \mathrm{Zn}$ kemudian dianalisis secara spasial berdasarkan berbagai sumber masukan dan menentukan faktor kontaminasi.

\section{MATERI DAN METODE}

Data diperoleh dari 6 (enam) titik pengambilan sampel yang terbentang di sepanjang pesisir Kota Makassar dan merepresentasikan aktivitas masyarakat pesisir. Pengambilan data meliputi pengukuran parameter oseanografi secara insitu (suhu, salinitas, pH, TSS, kecepatan dan arah arus) dan pengambilan sampel penelitian. Sampel pada penelitian ini berupa sedimen dasar dan air yang terdapat pada kolom air. Peta lokasi pengambilan data dapat diperhatikan pada Gambar 1.

Sampel sedimen dasar perairan diambil menggunakan Van Veen Grab Sampler yang dapat mengambil sampel sedimen hingga ketebalan $20 \mathrm{~cm}$ kemudian sampel tersebut dimasukkan ke dalam kantong polietilen dan 
disimpan pada coolbox. Sampel air diambil menggunakan horizontal water sampler yang diturunkan hingga kedalaman 1-5 meter dari permukaan air (50\% dari kedalaman) kemudian diawetkan menggunakan larutan $\mathrm{HNO}_{3}$ dan disimpan di dalam botol kedap cahaya dan disimpan dalam coolbox.

Analisis konsentrasi logam berat pada sampel air dan sedimen menggunakan Atomic Absorption Spectrophometer (AAS). Hasil analisis konsentrasi logam berat kemudian disajikan dalam bentuk grafik untuk membandingkan konsentrasi logam berat secara vertikal pada badan air dan sedimen. Konsentrasi logam berat kemudian dibandingkan dengan baku mutu logam berat yang mengacu pada Keputusan Menteri Lingkungan Hidup No. 51 tahun 2004 untuk baku mutu air laut dan ANZECC/ARMCANZ (2000) untuk sedimen.

Untuk mengetahui perbedaan besaran konsentrasi logam berat maka dilakukan uji ANOVA (analysis of variance). Pengujian berdasarkan keberadaan logam berat (sedimen dan kolom air) dan karakteristik sumber masukan yaitu aktivitas pelabuhan (PPI Untia dan PPI Paotere), muara sungai (S. Tallo dan S. Jeneberang), dan aktivitas wisata (Pantai Losari dan Tanjung Bayang).

Faktor kontaminasi atau contamination factor (CF) digunakan sebagai referensi untuk menentukan tingkat kontaminasi bahan pencemar logam berat berdasarkan konsentrasinya pada sedimen (Hakanson, 1980). Persamaan untuk menghitung faktor kontaminasi sebagai berikut :

$$
C F=\frac{C_{x}}{C_{b g}}
$$

Keterangan : $C_{x}=$ Konsentrasi logam berat hasil pengamatan; $C_{b g}=$ Konsentrasi logam berat di alam

Nilai $C_{b g}$ merupakan konsentrasi ratarata logam berat $X$ di lingkungan alami (Wardhani et al., 2017). Adapun nilai rata-rata alami konsentrasi logam (Taylor S.R, 1964) yaitu $\mathrm{Pb}$ sebesar 12,5 ppm, Cu sebesar $55 \mathrm{ppm}, \mathrm{Cd}$ sebesar 0,20 ppm, dan Zn sebesar $70 \mathrm{ppm}$. Adapun pengelompokan tingkat kontaminasi dapat diperhatikan pada Tabel 1.

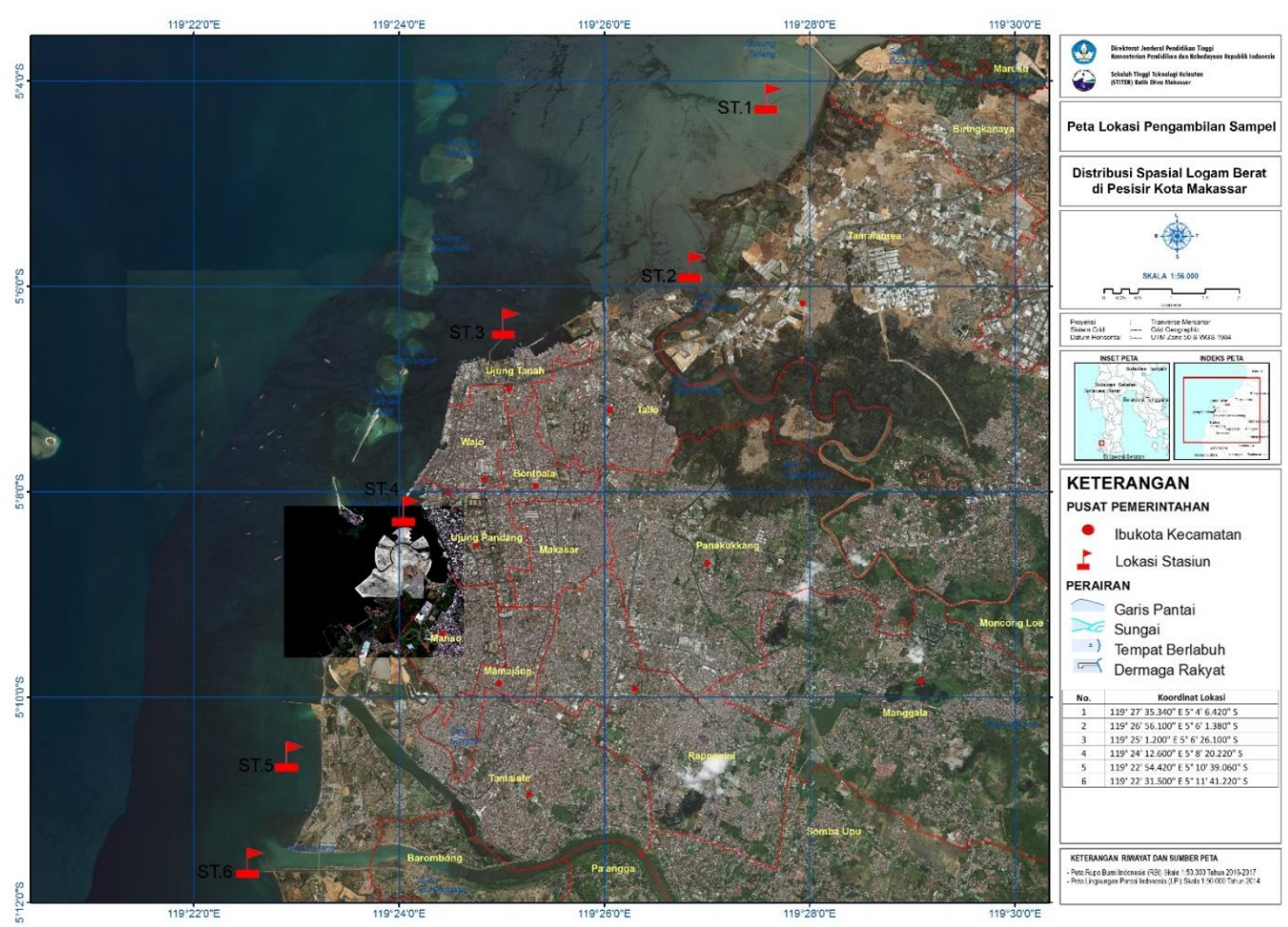

Gambar 1. Lokasi penelitian 
Tabel 1. Interpretasi faktor kontaminasi

\begin{tabular}{cc}
\hline Nilai CF & Tingkat Kontaminasi \\
\hline $\mathrm{CF}<1$ & Rendah \\
$1<\mathrm{CF}<3$ & Sedang \\
$3<\mathrm{CF}<6$ & Cukup \\
$\mathrm{CF}>6$ & Sangat Tinggi \\
\hline
\end{tabular}

Berdasarkan faktor kontaminasi dapat disusun urutan logam berat berdasarkan tingkat kontaminasinya.

\section{HASIL DAN PEMBAHASAN}

Aktivitas masyarakat yang berkaitan langsung dengan perairan pesisir Kota Makassar yaitu pelabuhan dan pariwisata. Selain kedua aktivitas tersebut, terdapat pula kegiatan perikanan dan pemukiman di sekitar muara sungai yang mengapit perairan pesisir Kota Makassar yaitu muara sungai Jeneberang dan Sungai Tallo.

Keberadaan kedua muara sungai tersebut menyebabkan perairan pesisir Kota Makassar cenderung dinamis namun secara dominan dipengaruhi oleh kondisi hidrooseanografi Selat Makassar (Jalil et al., 2014). Hasil pengukuran parameter oseanografi dapat diperhatikan pada Tabel 2 .

Kondisi oseanografi memengaruhi perilaku zat yang terdapat pada sedimen maupun badan air. Perairan pesisir Kota Makassar termasuk perairan yang dinamis sebab memiliki dua muara sungai dan termasuk tipe pasang surut campuran cenderung diurnal (Arifin et al., 2012). Mengacu pada standar deviasi yang relatif kecil maka dapat dinyatakan bahwa sebaran suhu, $\mathrm{pH}$, dan kecepatan arus di lokasi penelitian relatif seragam sedangkan perbedaan mencolok nampak pada parameter salinitas dan TSS. Nilai salinitas berkisar antara 21-35 ppm dengan nilai rata- rata 29,33 ppm, salinitas terendah ditunjukkan pada pengamatan di Muara Sungai Tallo (21 ppm) dan tertinggi pada Muara Sungai Jeneberang (35 ppm), nilai tersebut menunjukkan bahwa pada daerah Muara Sungai Tallo lebih dipengaruhi oleh arus air dari hulu sedangkan pada Muara Sungai Jeneberang cenderung dipengaruhi oleh arus air laut. Konsentrasi TSS tertinggi ditunjukkan pada pengamatan di Untia $(223,30 \mathrm{mg} / \mathrm{L})$ sedangkan pada stasiun lainnya berkisar antara 38,60-53,44 mg/L. Tingginya konsentrasi TSS di Untia disebabkan lokasi tersebut merupakan kawasan mangrove yang berdekatan dengan aktivitas pelabuhan dan muara Sungai Tallo sehingga sedimen yang tertahan pada mangrove dapat mengalami proses transport dan resuspensi akibat aktivitas muara (pasang-surut) maupun lalu lintas kapal.

Bahan pencemar logam berat di perairan mengalami proses bioakumulasi dan biomagnifikansi pada sedimen maupun secara partikulat pada kolom air sehingga berbahaya bagi biota (Asare et al., 2018). . Grafik distribusi logam berat secara vertikal pada setiap stasiun pengamatan dapat diperhatikan pada Gambar 2.

Konsentrasi logam berat $\mathrm{Pb}, \mathrm{Cu}, \mathrm{Cd}$, dan Zn tertinggi pada sampel sedimen secara berurutan yaitu pada Tanjung Bayang/TB $(0,0232 \mathrm{ppm})$, Paotere/Pao (0,0292 ppm), Muara Sungai Jeneberang/JB (0,162 ppm), dan Muara Sungai Tallo/TL (0,1655 ppm). Logam berat Cu pada sampel dari kolom air terdeteksi dengan nilai konsentrasi sangat kecil $(<0,005$ ppm) sedangkan lokasi pengamatan yang menunjukkan nilai logam berat jenis $\mathrm{Pb}, \mathrm{Cd}$, dan $\mathrm{Zn}$ tertinggi secara berurutan yaitu Pantai Losari/PL $(0,0115$ ppm), Untia $(0,0022$ ppm), dan Muara Sungai Tallo/TL (0,0305 ppm).

Tabel 2. Parameter oseanografi selama periode penelitian

\begin{tabular}{lccccccc}
\hline \multicolumn{1}{c}{ Parameter } & UNT & TL & PAO & PL & TB & JB & Rataan \pm SD \\
\hline Suhu $\left({ }^{\circ} \mathrm{C}\right)$ & 31 & 33 & 32 & 29 & 32 & 31 & $31,33 \pm 1,37$ \\
Salinitas (ppm) & 30 & 21 & 31 & 29 & 30 & 35 & $29,33 \pm 4,59$ \\
PH & 7,8 & 7,3 & 7,7 & 8,1 & 7,8 & 7,7 & $7,73 \pm 0,26$ \\
TSS (mg/L) & 223,30 & 53,44 & 42,72 & 40,08 & 38,60 & 40,70 & $73,14 \pm 73,76$ \\
Kecepatan Arus (m/s) & 0,1 & 0,2 & 0,1 & 0,1 & 0,1 & 0,3 & $0,15 \pm 0,08$ \\
\hline
\end{tabular}




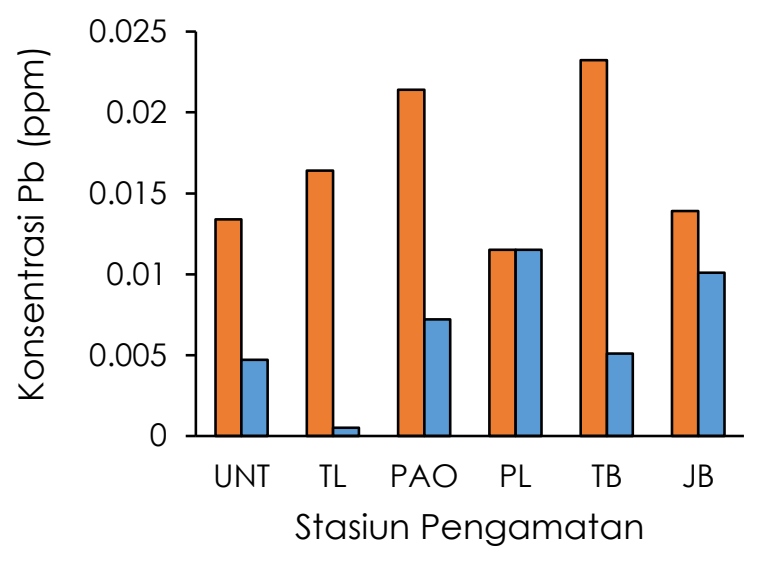

(a)

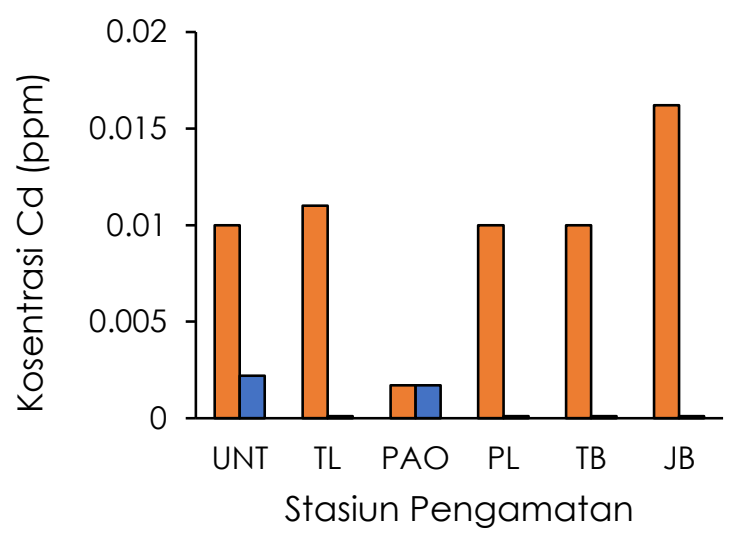

(c)

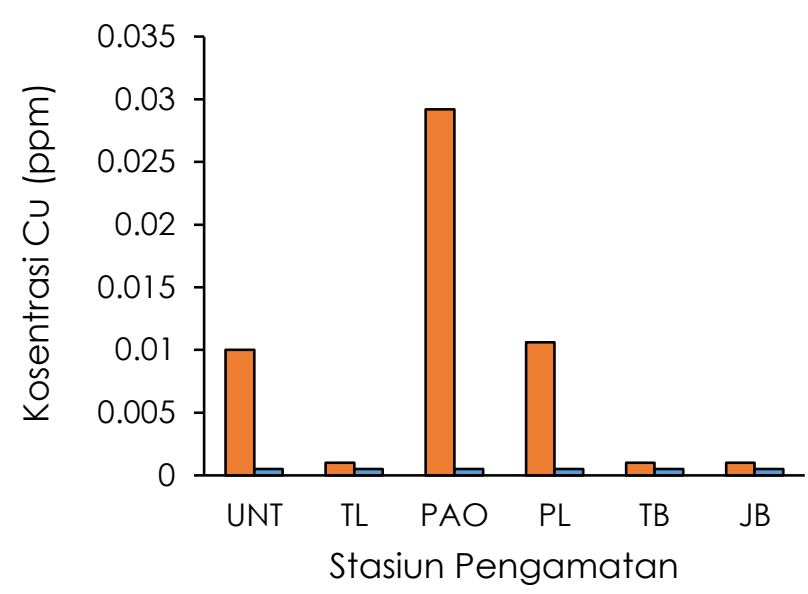

(b)

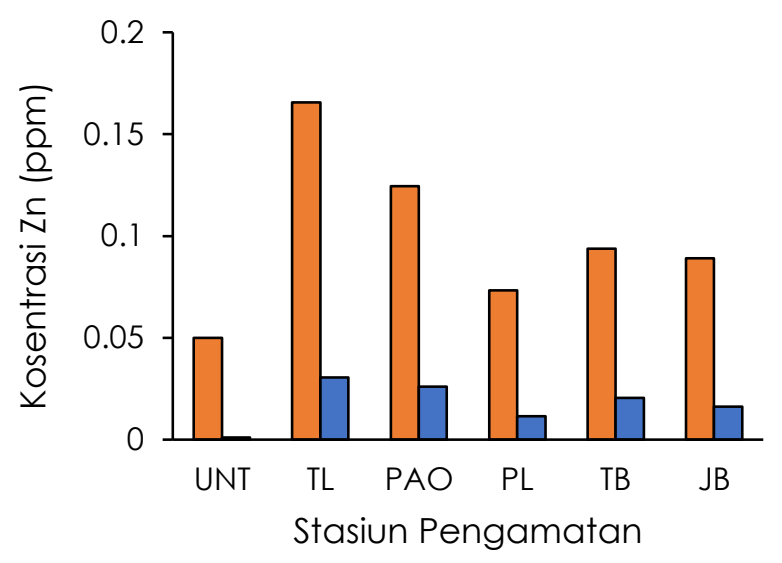

(d)

Gambar 2. Grafik distribusi konsentrasi logam berat secara vertikal (a) logam berat Pb, (b) logam berat Cu, (c) logam berat Cd, dan (d) logam berat Zn.

Keterangan : $\square$ = Sedimen; $\square=$ Air

Secara keseluruhan, nilai konsentrasi logam berat teramati lebih tinggi pada sedimen dibandingkan kolom air. Hasil uji ANOVA menunjukkan bahwa terdapat perbedaan signifikan $(p<\alpha: 0,05)$ antara konsentrasi logam berat $\mathrm{Pb}, \mathrm{Cd}$, dan $\mathrm{Zn}$ di sedimen dan kolom air sedangkan pada logam berat CU tidak terdapat perbedaan konsentrasi yang signifikan.

Logam berat jenis dapat teradsorpsi ke dalam sedimen dengan cepat melalui reaksi dengan bahan organik utamanya logam $\mathrm{Pb}$ sebab memiliki elektoronegativitas lebih tinggi dibandingkan $\mathrm{Cu}$ dan $\mathrm{Cd}$ (Chu et al., 2018; Czikkely et al., 2018). Konsentrasi logam berat pada kolom air cenderung dinamis dan berada dalam bentuk partikulat serta mudah mengalami proses perpindahan sehingga nilai konsentrasinya cenderung lebih rendah dibandingkan sedimen (Copaja et al., 2016; Supriyantini \& Soenardjo, 2016). Oleh karena itu konsentrasi logam berat pada sedimen cenderung lebih tinggi dibandingkan kolom air.

Secara spasial tidak terdapat perbedaan signifikan $(p>\alpha: 0,05)$ antara konsentrasi logam berat $\mathrm{Pb}, \mathrm{Cd}, \mathrm{Cu}$, dan $\mathrm{Zn}$ di daerah pelabuhan, muara sungai, dan lokasi aktivitas pariwisata. Kisaran konsentrasi logam berat yang ditemukan lebih rendah dibandingkan temuan Werorilangi et al., (2016) dan Najamuddin et al., (2016). Periode pengambilan data yang dilakukan pada masa pandemi menyebabkan beberapa 
aktivitas produksi masyarakat di pesisir tidak berjalan normal sehingga mengurangi bahan pencemar yang lepas ke perairan pesisir (Cherif et al., 2020).

\section{Konsentrasi logam berat dan baku mutu}

Logam berat di perairan tidak dapat diurai oleh organisme sehingga dalam jangka panjang memberi efek negatif bagi ekosistem karena bersifat toksik (Czikkely et al., 2018). Eksistensi logam berat dalam bentuk sedimen pada substrat dasar maupun partikulat di badan air merupakan ancaman serius bagi biota perairan sehingga perlu dipantau setiap saat. Hasil perbandingan konsentrasi logam berat yang diteliti terhadap baku mutu (BM) dapat diperhatikan pada Tabel 3 dan Tabel 4. Konsentrasi logam berat pada sedimen masih berada jauh di bawah baku mutu ANZECC \& ARMCANZ (2000) maupun Swedish Environmental Protection Agency (2000). Pada setiap lokasi pengambilan sampel sedimen menunjukkan keberadaan logam berat yaitu $\mathrm{Pb}(0,05-0,0232 \mathrm{ppm}), \mathrm{Cd}(0,0017-$ 0,0162 ppm), dan Zn (0,05-0,1655 ppm). Logam berat Cu pada sedimen hanya terdeteksi pada tiga stasiun pengamatan yaitu di Muara Sungai Tallo (0,0106 ppm), PPI Paotere $(0,0292 \mathrm{ppm})$, dan Tanjung Bayang $(0,01 \mathrm{ppm})$.

Pada kolom air, konsentrasi logam berat $\mathrm{Pb}$ dan $\mathrm{Cd}$ teramati melebihi baku mutu yang telah ditetapkan berdasarkan KepMenLH nomor 51 tahun 2004. Logam berat Cu memiliki mobilitas rendah di kolom air sehingga mudah mengalami adsorpsi di sedimen melalui ikatan kuat dengan bahan organik (Supriyantini dan Soenardjo, 2016).

Logam timbal di Pantai Losari $(0,0115$ ppm) dan Muara Sungai Jeneberang $(0,0101$ ppm) telah melampaui baku mutu timbal di perairan. Keberadaan logam berat yang melebihi baku mutu pada kolom air merupakan ancaman bagi kelangsungan biota perairan sebab mudah mengalami proses perpindahan dan bersifat toksik.

Logam berat $\mathrm{Pb}$ di sekitaran Pantai Losari diduga berasal dari limbah anorganik yang dihasilkan outlet beberapa aktivitas di sekitar Pantai Losari yaitu rumah sakit, restoran, dan perhotelan. Penelitian Maricar et al. (2015) memperoleh konsentrasi Pb di sekitar Anjungan Pantai Losari mencapai 2,32 ppm sedangkan Supriadi (2016) menemukan konsentrasi $\mathrm{Pb}$ di lokasi yang sama mencapai 2,372 ppm. Hal tersebut menunjukkan bahwa konsentrasi $\mathrm{Pb}$ di sekitar Pantai Losari telah melampaui baku mutu secara konsisten.

Tingginya konsentrasi $\mathrm{Pb}$ pada air di sekitar Muara Sungai Jeneberang berasal dari pengikisan alami serta resuspensi sedimen dari dasar perairan mengingat kecepatan arus di sekitar Muara Sungai Jeneberang mencapai

Tabel 3. Perbandingan konsentrasi logam berat pada sedimen dan baku mutu

\begin{tabular}{cccccccc}
\hline \multirow{2}{*}{ Parameter } & \multirow{2}{*}{$\mathrm{BM}$} & $\mathrm{UNT}$ & $\mathrm{TL}$ & $\mathrm{PAO}$ & $\mathrm{PL}$ & $\mathrm{TB}$ & $\mathrm{JB}$ \\
\hline $\mathrm{Pb}$ & 50 & 0,0164 & 0,0115 & 0,0214 & 0,0139 & 0,0134 & 0,0232 \\
$\mathrm{CU}$ & 65 & $<0,01$ & 0,0106 & 0,0292 & $<0,01$ & 0,01 & $<0,01$ \\
$\mathrm{Cd}$ & 1,5 & 0,011 & 0,01 & 0,0017 & 0,0162 & 0,01 & 0,01 \\
$\mathrm{Zn}$ & 200 & 0,1655 & 0,0733 & 0,1245 & 0,0891 & 0,05 & 0,0937 \\
\hline
\end{tabular}

Keterangan : BM mengacu pada ANZECC/ARMCANZ (2000)

Tabel 4. Perbandingan konsentrasi logam berat pada kolom air dan baku mutu

\begin{tabular}{cccccccc}
\hline \multirow{2}{*}{ Parameter } & \multirow{2}{*}{$\mathrm{BM}$} & $\mathrm{UNT}$ & $\mathrm{TL}$ & $\mathrm{PAO}$ & $\mathrm{PL}$ & $\mathrm{TB}$ & $\mathrm{JB}$ \\
\hline $\mathrm{Pb}$ & 0,008 & 0,0047 & $<0,005$ & 0,0072 & $0,0115^{*}$ & 0,0051 & $0,0101^{*}$ \\
$\mathrm{Cu}$ & 0,008 & $<0,005$ & $<0,005$ & $<0,005$ & $<0,005$ & $<0,005$ & $<0,005$ \\
$\mathrm{Cd}$ & 0,001 & $0,0022^{*}$ & $<0,001$ & $0,0017^{*}$ & $<0,001$ & $<0.001$ & $<0,001$ \\
$\mathrm{Zn}$ & 0,05 & $<0,01$ & 0,0305 & 0,0261 & 0,0115 & 0,0204 & 0,0162 \\
\hline
\end{tabular}

Keterangan : BM mengacu pada KepMenLH no. 51 tahun 2004; *melebihi baku mutu 
$0,3 \mathrm{~m} / \mathrm{s}$. Aktivitas pengerukan material yang dilakukan di sepanjang bantaran Sungai Jeneberang juga berkontribusi terhadap konsentrasi timbal di sekitar muara sungai (Werorilangi et al., 2019).

Logam kadmium yang melampaui baku mutu teridentifikasi pada pengamatan di PPI Untia $(0,0022 \mathrm{ppm})$ dan PPI Paotere $(0,0017$ ppm). Sumber kadmium dapat berasal dari faktor alami seperti pengikisan lapisan kulit bumi, atmosfer, dan aktivitas geologi laut. Masukan kadmium juga dapat berasal dari aktivitas manusia (Rumahlatu et al., 2012). Konsentrasi logam berat kadmium yang melebih baku mutu pada dua lokasi dengan identitas aktivitas pelabuhan menunjukkan bahwa kegiatan transportasi dan perbaikan kapal berkontribusi terhadap terlampauinya baku mutu logam berat kadmium di perairan (Hasan et al., 2016).

\section{Faktor kontaminasi logam berat}

Hasil perhitungan contaminant factor (CF) berdasarkan konsentrasi logam berat di sedimen pada Tabel 5 menunjukkan bahwa konsentrasi logam berat pada sedimen berada pada tingkat kontaminasi rendah $(C F<1)$ atau tidak tercemar. Nilai CF menunjukkan bahwa konsentrasi logam berat pada sedimen di perairan pesisir Kota Makassar belum berbahaya bagi biota.

Rendahnya kontaminasi logam berat pada sedimen di perairan pesisir juga ditemukan pada hasil penelitian Budiyanto \& Lestari (2017) di Teluk Jakarta, Sukaryono (2018) di pesisir Teluk Ambon, Yona et al. (2018) di Pantai Barat Perairan Selat Bali, Al-Edresy et al. (2019) di Perairan Pesisir Selatan Yaman, dan Xie et al., (2016) di Perairan Dongying. Salah satu faktor penyebab rendahnya nilai faktor kontaminasi yaitu tidak adanya nilai rerata konsentrasi logam berat alami di lokasi penelitian.

Secara berurutan nilai contaminant factor yang ditemukan pada lokasi penelitian yaitu $\mathrm{Cd}>\mathrm{Zn}>\mathrm{Pb}>\mathrm{Cu}$ dimana pola serupa juga ditemukan pada penelitian Ahmad (2013) di perairan Pulau Bangka. Penelitian Chu et al. (2018) menyimpulkan bahwa logam $\mathrm{Cd}$ merupakan bahan pencemar utama pada sedimen di perairan Beijing, China.
Tabel 5. Nilai faktor kontaminan logam berat pada sedimen

\begin{tabular}{ccccc}
\hline \multirow{2}{*}{ Lokasi } & $\mathrm{Pb}$ & $\mathrm{Cu}$ & $\mathrm{Cd}$ & $\mathrm{Zn}$ \\
\hline UNT & 0.0013 & $<0,01$ & 0,0550 & 0,0024 \\
TL & 0,0009 & 0,0002 & 0,0500 & 0,0010 \\
PAO & 0,0017 & 0,0005 & 0,0085 & 0,0018 \\
PL & 0,0011 & $<0,01$ & 0,0810 & 0,0013 \\
TB & 0,0011 & 0,0002 & 0,0500 & 0,0007 \\
JB & 0,0019 & $<0,01$ & 0,0500 & 0,0013 \\
\hline
\end{tabular}

\section{KESIMPULAN}

Hasil penelitian menunjukkan bahwa terdapat perbedaan konsentrasi yang signifikan antara logam berat $\mathrm{Pb}, \mathrm{Cd}$, dan $\mathrm{Zn}$ di sedimen dan kolom air sedangkan pada logam Cu tidak terdapat perbedaan. Secara spasial tidak terdapat perbedaan signifikan antara konsentrasi logam berat di kawasan pelabuhan, muara sungai, dan pusat aktivitas wisata. Berdasarkan baku mutunya maka konsentrasi logam berat pada sedimen tidak melebihi baku mutu dan menunjukkan tingkat kontaminasi yang rendah sedangkan pada kolom air mengindikasikan bahwa logam berat $\mathrm{Pb}$ dan $\mathrm{Cd}$ telah melebihi baku mutu pada beberapa stasiun pengamatan. Berdasarkan faktor kontaminasinya maka pada lokasi penelitian diperoleh urutan konsentrasi logam berat yaitu $\mathrm{Cd}>\mathrm{Zn}>\mathrm{Pb}>\mathrm{Cu}$.

\section{UCAPAN TERIMA KASIH}

Penelitian ini dapat terlaksana atas dukungan dana program Hibah Penelitian Kementerian Riset dan Teknologi/BRIN tahun anggaran 2020.

\section{DAFTAR PUSTAKA}

Ahmad, F. 2013. Distribution And Prediction On Heavy Metals Pollution Level (Pb, Cd, Cu, $\mathrm{Zn}$, and Ni) IN Sediment In Bangka Island Waters Using Load Pollution Index And Geoaccumulation Index. Jurnal IImu Dan Teknologi Kelautan Tropis, 5(1):170-181. doi : 10.29244/jitkt.v5i 1.7763

Al-Edresy, M.A., Wasel, O.S. \& Al-Hagibi, H.A. 2019. Ecological risk assessment of heavy metals in coastal sediments between AlHaymah and Al-Mokha, south red sea, Yemen. International Journal of 
Hydrology, 3(2):159-173. doi : 10.15406/ijh. 2019.03.00177

Amri, S.N., Adrianto, L., \& Bengen, D.G. 2018. Spatial Projection of Land Use and Its Connection With Urban Ecology Spatial Planning in the Coastal City, Case Study in Makassar City, Indonesia. International Journal of Remote Sensing and Earth Sciences, 14(2):95-110. doi : 10.30536/j.jijes es.2017.v14.a2715

ANZECC \& ARMCANZ. 2000. Toxicant default guideline values for sediment quality. Australian and New Zealand.

Arifin, T., Azis, M.F., \& Metode, B. 2012. Kondisi arus pasang surut di perairan pesisir kota Makassar, Sulawesi Selatan. Depik Jurnal, 1 (3):183-188. doi : 10.13170/depik.1.3.113

Asare, M.L., Cobbina, S.J., Akpabey, F.J., Duwiejuah, A.B., \& Abuntori, Z.N. 2018. Heavy metal concentration in water, sediment and fish species in the bontanga reservoir, Ghana. Toxicology and Environmental Health Sciences, 10(1):4958. doi : 10.1007/s13530-018-0346-4

Badan Pusat Statistik. 2019. Ekonomi Indonesia Tahun 2018. BPS.

Budiyanto, F., \& Lestari, L. 2017. Temporal and Spatial Distribution of Heavy Metal in Sediment of Urban Coastal Waters: A Case Study in Jakarta Bay, Indonesia. Bulletin of the Marine Geology, 32(1):1-10. doi : 10.32693/bomg.32.1.2017.364

Cherif, E.K., Vodopivec, M., Mejjad, N., Esteves, J.C.G., \& Simonovi, S. 2020. COVID-19 Pandemic Consequences on Coastal Water. Water.

Chu, Z., Gu, W., \& Li, Y. 2018. Adsorption mechanism of heavy metals in heavy metal/pesticide coexisting sediment systems through factional factorial design assisted by 2D-QSAR models. Polish Journal of Environmental Studies, 27(6): 2451-2462. doi:10.15244/pjoes/80962

Copaja, S.V., Nuñez, V.R., Muñoz, G.S., González, G.L., Vila, I., \& Véliz, D. 2016. Heavy metal concentrations in water and sediments from affluents and effluents of Mediterranean Chilean reservoirs. Journal of the Chilean Chemical Society, 61(1): 2797-2804. doi : 10.4067/S0717-970720160 00100011

Czikkely, M., Neubaver, E., Fekete, I., Ymeri, P., \& Fogarassy, C. 2018. Review of heavy metal adsorption processes by several organic matters from wastewaters. Water Switzerland, 10(10):1-15. doi : 10.3390/ W10101377

Dahuri, R., Rais, J., Ginting, S. P., \& Sitepu, M.J. 2013. Pengelolaan Sumber Daya Wilayah Pesisir dan Lautan secara Terpadu. Balai Pustaka.

Drira, Z., Sahnoun, H., \& Ayadi, H. 2017. Spatial distribution and source identification of heavy metals in surface waters of three coastal areas of Tunisia. Polish Journal of Environmental Studies, 26(3):1057-1069. doi : 10.15244/pjoes/67529

Hakanson, L. 1980. An ecological risk index for aquatic pollution control.a sedimentological approach. Water Research, 14(8):9751001. doi : 10.1016/00 43-1354(80)90143-8

Hasan, M. R., Khan, M. Z. H., Khan, M., Aktar, S., Rahman, M., Hossain, F., \& Hasan, A. S. M. M. 2016. Heavy metals distribution and contamination in surface water of the Bay of Bengal coast. Cogent Environmental Science, 2(1):1-12. doi : 10.1080/233118 43.2016 .1140001

Hettige, N., Weerasekara, K., Azmy, S., \& Jinadasa, K. 2014. Water Pollution in Selected Coastal Areas in Western Province, Sri Lanka: A Baseline Survey. Journal of Environmental Professionals Sri Lanka, 3(2):12-24. doi : 10.4038/jepsl.v3i2. 7843

Jalil, A.R., Nurjannah, N., lqbal, A.B., \& Hatta, M. 2014. Karakter Oseanografi Perairan Makassar Terkait Zona Potensial Penangkapan Ikan Pelagis Kecil Pada Musim Timur. Jurnal IPTEKS Pemanfaatan Sumberdaya Perikanan, 1 1 1):69-80.

Baku Mutu Air Laut, 1 2004. http://www.kelair. bppt.go.id/Hukum/data/kepmen/bml/51 -2004.pdf

Maricar, M.I., Bakri, B. \& Idamansari, W.O. 2015. Analisis Tingkat Pencemaran Air Laut Di Pantai Losari Makassar Untuk Wisata Bahari. Universitas Hasanuddin.

Najamuddin, Prartono, T., Sanusi, H.S. \& Nurjaya, I.W. 2016. Distribution And Behaviour of Dissolved And Particulate $\mathrm{Pb}$ And Zn In Jeneberang Estuary, Makassar. Jurnal Ilmu dan Teknologi Kelautan Tropis, 8(1):11-28. doi : 10.29244/jitkt.v8i1.12494

Noor, R.J. 2018. Characteristics And Sediment Distribution of Coastal Mamuju District. Marina Chimica Acta, 19(1):20-27.

Rangkuti, A.M., Cordova, M.R., Rahmawati, A., 
Yulma, \& Adimu, H.E. 2017. Ekosistem Pesisir dan Laut Indonesia (S. B. Hastuti \& R. Damayanti (eds.)). Bumi Aksara.

Rumahlatu, D., Corebima, A.D., Amin, M., \& Rachman, F. 2012. Kadmium dan Efeknya terhadap Ekspresi Protein Metallothionein pada Deadema setosum (Echinoidea; Echinodermata). Jurnal Penelitian Perikanan, 1(1):25-33.

Setiawan, H. 2015. Akumulasi dan Distribusi Logam Berat pada Vegetasi Mangrove di Pesisir Sulawesi Selatan. Jurnal IImu Kehutanan, 7(1):12-24. doi : 10.22146/jik. 6134

Sukaryono, I.D. 2018. Pemantauan Kandungan Logam Berat Pb Dan Cd Pada Sedimen Di Pesisir Teluk Ambon Dalam Sebagai Indikasi Tingkat Pencemaran Monitoring. Majalah Biam, 14(1):1-7. doi : 10.29360/mb. v14il.3554

Supriadi. 2016. Analisis Kadar Logam Berat Timbal (Pb), Kadmium (Cd) dan Merkuri (Hg) Pada Wisata Pantai Akkarena dan Tanjung Bayang Makassar [UIN Alauddin Makassar].

Supriyantini, E. \& Soenardjo, N. 2016. Kandungan Logam Berat Timbal (Pb) Dan Tembaga (Cu) Pada Akar Dan Buah Mangrove Avicennia marina Di Perairan Tanjung Emas Semarang. Jurnal Kelautan Tropis, 18(2):98-106. doi : 10.14710/jkt.v18 i2.520

Swedish Environmental Protection Agency. 2000. Coasts and Seas. In Design (1st ed.). SEPA.

Taylor S.R. 1964. T48-Abundance of chemical elements in the continental crust: a new table. Geochimica et Cosmochimica Acta, 28:1273-1285.

Wanna, M., Yanto, S., \& Kadirman, K. 2018. Analisis Kualitas Air Dan Cemaran Logam Berat Merkuri (Hg) Dan Timbal (Pb) Pada Ikan Di Kanal Daerah Hertasning Kota Makassar. Jurnal Pendidikan Teknologi Pertanian, 3:197-210. doi : 10.26858/jptp. v3i0.5719
Wardhani, E., Roosmini, D., \& Notodarmojo, S. 2017. Pencemaran Kadmium Di Sedimen Waduk Saguling Provinsi Jawa Barat. Jurnal Manusia Dan Lingkungan, 23(3): 285-294. doi : 10.22146/jml.18802

Werorilangi, S., Noor, A., Samawi, M. F., Faizal, A., \& Tahir, A. 2019. Sebaran Spasial Logam Pb, Cd, Cu, Zn Dan Fraksi Geokimia Di Sedimen Perairan Pantai Kota Makassar. Jurnal IImu Kelautan Spermonde, 5(1):21-28. doi : 10.20956/jiks. v5i 1.7029

Werorilangi, S., Samawi, M. F., Rastina, Tahir, A., Faizal, A. \& Massinai, A. 2016. Bioavailability of $\mathrm{Pb}$ and $\mathrm{CU}$ in sediments of vegetated seagrass, enhalus acoroides, from spermonde islands, makassar, south sulawesi, indonesia. Research Journal of Environmental Toxicology, 10(2):126-134. doi : 10.3923/rjet.2016.126.134

Xie, Z., Zhang, H., Zhao, X., Du, Z., Xiang, L., \& Wang, W. 2016. Assessment of Heavy Metal Contamination and Wetland Management in a Newly Created Coastal Natural Reserve, China. Journal of Coastal Research, 32(2):374-386. doi : 10.2112/ JCOASTRES-D-14-00222.1

Yan, X., Liu, M., Zhong, J., Guo, J., \& Wu, W. 2018. How human activities affect heavy metal contamination of soil and sediment in a long-term reclaimed area of the Liaohe River Delta, North China. Sustainability (Switzerland), 10(2):1-19. doi: 10.3390/su10020338

Yona, D., Hikmah, S., Sari, J., Kretarta, A., Putri, C. R., Aini, M. N., Arif, M., \& Adi, A. 2018. Distribusi dan Status Kontaminasi Logam Berat pada Sedimen di Sepanjang Pantai Barat Perairan Selat Bali , Banyuwangi Distribution and Contamination Status of Heavy Metals in the Surface Sediments along Western Coast of Bali Strait, Banyuwangi Abstrak Pe. Torani, 1(2):2130. doi : 10.35911 /torani.v1i2.4439 